\title{
Pandangan filsafat terhadap ilmu pedagogi olahraga
}

\section{Philosophical view of the science of sports pedagogy}

\section{Putu Agus Dharma Hita}

Ilmu Keolahragaan, Pascasarjana, Universitas Negeri Yogyakarta, Yogyakarta, Indonesia

Received: 05 October 2020; Accepted 09 November 2020; Published 04 December 2020

\begin{abstract}
ABSTRAK
Ilmu pedagogi bagi seorang guru sangatlah penting dikarenakan dengan menguasai ilmu pedagogi proses pembelajaran yang dilaksanakan akan mendapatkan hasil yang maksimal serta sesuai dengan tujuan dilaksanakannya pembelajaran tersebut. Penelitian ini bertujuan tujuan mengetahui apa saja faktor-faktor yang seharusnya dimiliki oleh seorang guru sehingga dalam suatu proses pembelajaran guru mampu untuk menciptakan suatu pembelajaran yang baik, strategi dan gaya mengajar yang tepat, serta pengetahuan dan pengalaman yang maksimal. Metode yang digunakan dalam penelitian ini yaitu menggunakan metode studi literatur, yaitu data dikumpulkan dengan metode studi pustaka. Data akan dikompulasi, dianalisis, dan disimpulkan sehingga mendapatkan sebuah kesimpulan. Pendidikan dalam olahraga harus diberikan sejak dini pada anak seperti pendidikan formal di sekolah. Dalam proses pendidikan, tidak akan terlepas dari peran seorang guru di kelas. Peran guru merupakan penerapan dari ilmu pedagogi. Pedagogi olahraga merupakan disiplin ilmu keolahragaan yang mempunyai potensi untuk mengintegrasikan subdisiplin ilmu keolahragaan untuk dapat melandasi semua praktik dalam bidang keolahragaan yang memiliki maksud dan tujuan untuk dapat mendidik. Guru harus mampu mempunyai pengetahuan teori yang luas, penerapan di kelas dalam menggunakan metode-metode yang tepat, serta mampu mengelola kelas agar proses pembelajaran dapat berjalan dengan baik dan mencapai hasil yang maksimal. Karena, jika guru hanya menguasai teoriteori tanpa adanya kemampuan dalam mengelola kelas dengan menggunakan metode-metode pembelajaran yang tepat, harapan dari hasil yang diinginkan tidak akan tercapai. Jadi antara pengetahuan teori dan penerapan metodemetode harus seimbang dalam proses pembelajaran. Semua metode, media, referensi, dan sebagainya tidak akan berarti apabila seorang guru tidak mampu dalam memerankan tugasnya dengan baik.
\end{abstract}

Kata Kunci: Pendidikan; Pedagogi; Filsafat; Olahraga Keyword: Education; Pedagogy; Philosophy; Sports *Corresponding Author
Email: putuagusdharma@yahoo.com https://doi.org/10.25299/es:ijope.2020.vol1(2).5671

How To Cite: Hita, I. P. A. D. (2020). Pandangan filsafat terhadap ilmu pedagogi olahraga. Edu Sportivo: Indonesian Journal of Physical Education, 1(2), 66-78. https://doi.org/10.25299/es:ijope.2020.vol1(2).5671 


\section{PENDAHULUAN}

Filsafat ilmu pada dasarnya merupakan cara bagaimana kita menelaah secara kritis pada metode yang digunakan dalam mengkaji suatu ilmu tertentu, baik itu dikaji secara secara empiris maupun dikaji rasional (Kirom, 2011). Jika dikaji secara mendalam mengenai perkembangan ilmu di Indonesia, filsafat selalu menjadi landasan utama baik dalam hal perkembangan ilmu, pendidikan, dan metode yang digunakan dalam mengkaji suatu ilmu tertentu. Perkembangan ilmu olahraga akan terus berkembang seiring berjalannya waktu. Agar terciptanya sebuah prestasi yang diharapkan, maka diperlukan dukungan dari berbagai pihak, termasuk ilmu pengetahuan dan teknologi atau IPTEK. Peran teknologi informasi dalam suatu proses pendidikan, selain dapat membantu siswa dalam belajar juga mempunyai pengaruh yang besar terhadap guru, terutama dalam menggunakan fasilitas yang memiliki tujuan untuk memperkaya kemampuan mengajar (Budiman, 2017). IPTEK disini dimaksud bukan berarti dalam bentuk penggunaan mesin, tetapi pemanfaatan pengetahuan dan teknologi dalam olahraga untuk mencapai prestasi yang maksimal. Maka dari itu, agar dapat meningkatkan sebuah prestasi yang maksimal dan dapat memecahkan masalahmasalah yang ada, maka sangat diperlukan peran besar dari seorang peneliti dan pemikir dalam menciptakan temuan-temuan baru dalam bidang olahraga.

Pendidikan dalam olahraga harus diberikan sejak dini pada anak seperti pendidikan formal di sekolah. Dalam proses pendidikan, tidak akan terlepas dari peran seorang guru di kelas. Peran guru merupakan penerapan dari ilmu pedagogi. Pedagogi berasal dari bahasa Yunani yaitu kata "paedagogeo", dimana terdiri dari kata "pais genetif", kata "paidos" yang berarti anak, sedangkan kata "agogo" yang berarti memimpin, sehingga pedagogi dapat diartikan sebagai memimpin anak. Sementara itu, dalam Bahasa Inggris pengertian kata pedagogi (pedagogy) dapat diartikan sebagai suatu teori pengajaran, dimana seorang guru berusaha untuk dapat memahami suatu bahan ajar, mengenal siswa lebih dalam dan menentukkan cara untuk mengajar dalam suatu proses pembelajaran di kelas (Hiryanto, 2017).

Guru sebagai tenaga profesional bertugas merencanakan dan melaksanakan pembelajaran, menilai hasil pembelajaran, melakukan pembimbingan dan pelatihan, melakukan penelitian, membantu pengembangan dan pengembangan program sekolah serta mengembangkan profesionalitasnya (Apriani, Alpen, \& Arismon, 2020). Kemampuan guru dalam menyampaikan ilmu kepada peserta didik serta mengelola pembelajaran di kelas merupakan bagian dari keterampilan pedagogi yang harus dimiliki oleh setiap guru. Pedagogi sering didefinisikan sebagai gaya dalam proses mengajar, masalah kepribadian seorang guru, serta mekanisme mengontrol kelas untuk mendorong proses pembelajaran. Pedagogi olahraga (sport pedagogy) merupakan disiplin ilmu keolahragaan yang mempunyai potensi untuk mengintegrasikan subdisiplin ilmu keolahragaan untuk dapat melandasi semua praktik dalam bidang keolahragaan yang memiliki maksud dan tujuan untuk dapat mendidik (Mutohir, 2015).

Ilmu pedagogi olahraga sangat penting dimiliki oleh seorang guru dalam proses pembelajaran di kelas. Melalui penerapan ilmu pedagogi olahraga saat proses pembelajaran, guru secara tidak langsung akan mendidik siswa melalui kegiatan pembelajaran tersebut (Danardono, 2015). Oleh sebab itu, peran guru sangatlah penting dalam penyampaian materi agar siswa lebih mudah mengerti dalam menerima materi yang diberikan oleh guru. Permasalahan pendidikan yang berhubungan ataupun yang berkaitan dengan proses pembelajaran yaitu tenaga pendidik masih kurang dan belum berkompeten dalam melaksanakan tugasnya (Rahman, 2018). Fakta yang terjadi dilapangan masih menunjukan bahwa proses pendidikan jasmani masih memiliki 
setumpuk masalah, terutama yang berkaitan dengan kualitas dalam proses pembelajaran pendidikan jasmani, dimana masalahnya terletak pada ilmu pedagogi (Husdarta, 2010). Pendidikan jasmani adalah penyampaian pendidikan melalui tubuh yang dapat dilihat sebagai pelengkap pelatihan intelektual dalam sistem pendidikan secara keseluruhan (Haag, 1989). Pendidikan jasmani sangat erat kaitannya dengan pedagogi olahraga, kemampuan guru dalam mengelola pembelajaran dikelas sangat berpengaruh terhadap hasil peserta didik selama mengikuti proses pembelajaran (Alfrey, Enright, \& Rynne, 2017).

Proses pembelajaran dapat dikatakan sebagai suatu interaksi antara guru dengan siswa dimana tujuannya untuk mencapai suatu pembelajaran yang diinginkan. Ketika kita berbicara mengenai proses pembelajaran, tidak akan terlepas dari ruang lingkup sekolah yang ada di sekitar kita, yaitu mata pelajaran yang diajarkan oleh guru . Salah satu mata pelajaran tersebut adalah mata pelajaran Pendidikan Jasmani, Olahraga dan Kesehatan (PJOK). PJOK merupakan salah satu mata pelajaran yang wajib diberikan secara formal di sekolah. PJOK merupakan media yang digunakan untuk mendorong perkembangan keterampilan motorik ataupun gerak dasar motorik anak serta pola hidup sehat yang bertujuan untuk merangsang perkembangan dan pertumbuhan anak secara menyeluruh (Rusmawati, 2016). Sebagai seorang guru yang professional dalam pendidikan jasmani, seorang guru diharapkan mampu mengajarkan berbagai keterampilan gerak dasar dan teknik dasar yang bertujuan untuk mendapatkan hasil yang maksimal dalam proses pembelajaran. Peran guru dalam proses pembelajaran sangatlah penting, karena berhasil tidaknya suatu pembelajaran tergantung peran guru tersebut mampu atau tidaknya mengelola dan mengorganisir komponen-komponen yang mendukung dalam suatu proses pembelajaran seperti siswa, sumber, media, dan lingkungan belajar. Kualitas proses pembelajaran sangat menentukan hasil belajar dari siswa, oleh karena itu guru harus mampu merancang suatu proses pembelajaran dengan baik agar siswa mudah dalam mengikuti proses pembelajaran. Faktor guru sangat mempengaruhi kualitas pembelajaran di sekolah karena guru merupakan alat pendukung pembelajaran yang bertugas mempersiapkan dan mengelola pembelajaran di sekolah. Dalam hal ini guru diharapkan dapat menyiapkan model pembelajaran yang baik dan tepat sehingga siswa lebih mudah membangun pemahamannya sendiri. Jadi, seorang guru harus memiliki kemampuan dalam menciptakan suatu proses pembelajaran, strategi dan gaya dalam mengajar, ilmu dan seni dalam proses pembelajaran, serta pengetahuan dan pengalaman yang baik sehingga dapat mencapai hasil belajar yang diinginkan.

Pada kenyataannya, berdasarkan observasi yang dilakukan oleh penulis dilapangan, masih banyak guru yang masih dianggap kurang maksimal dalam proses pembelajaran seperti penyampaian materi yang kurang baik dan kemampuan dalam mengelola kelas belum maksimal, sehingga siswa masih kurang kurang fokus dan tidak dapat menerima materi dengan maksimal, sehingga pada akhirnya akan berpengaruh terhadap hasil belajar siswa. Selama ini proses pembelajaran lebih di dominasi oleh guru, dimana guru lebih banyak berperan di dalam kelas sebagai perekayasa tingkah laku siswa, proses pembelajaran lebih berpusat pada guru, prilaku siswa dibentuk melalui suasana pembelajaran yang sistematis dan kaku, dan siswa lebih banyak dituntut untuk menyelesaikan semua aktivitasnya dengan lingkungan belajar yang ada sehingga siswa menjadi pasif saat proses pembelajaran. Persoalan tentang rendahnya kualitas pembelajaran pendidikan jasmani akan berdampak pada munculnya masalah - masalah lain, seperti peserta didik memiliki tingkat kebugaran jasmani yang rendah dan keterampilan gerak dasar yang tidak memadai. Permasalahan di atas diperkuat dalam 
sebuah penelitian, dimana dikatakan bahwa beberapa permasalahan kemampuan guru dalam melaksanakan pembelajaran antara lain adalah metode yang digunakan kurang bervariasi, guru jarang dalam menggunakan media atau alat peraga dalam proses pembelajaran yang bertujuan untuk mempermudah menyampaikan materi, keterampilan guru dalam mengajar masih kurang, masih ada guru yang menghukum siswa karna tidak membuat tugas dengan cara berdiri di depan kelas, guru masih berpedoman dengan buku paket dalam proses pembelajaran, siswa masih kurang aktif dalam proses pembelajaran, dan penyusunan tempat duduk masih permanen atau tidak berubah-ubah (Rifma, 2013).

Berdasarkan latar belakang masalah yang diuraikan di atas, maka tujuan dilakukan penelitian ini adalah untuk mengetahui apa saja faktor-faktor yang seharusnya dimiliki oleh seorang guru sehingga dalam suatu proses pembelajaran guru mampu untuk menciptakan suatu pembelajaran yang baik, strategi dan gaya mengajar yang tepat, serta pengetahuan dan pengalaman yang maksimal.

\section{METODE PENELITIAN}

Metode yang digunakan dalam penelitian ini yaitu menggunakan metode studi literatur. Data dikumpulkan dengan metode studi pustaka yang berasal dari penelitianpenelitian sebelumnya, buku, serta kumpulan artikel-artikel yang bersumber dari jurnal-jurnal ilmiah. Artikel yang terkumpul sebelumnya akan diidentifikasi dengan temuan sebanyak 34 artikel di Google Scholar dan 14 temuan artikel di Scopus. Selanjutnya artikel tersebut discreening menjadi 25 artikel Nasional dan 9 artikel Internasional. Hasil screening yang sesuai dan yang dibutuhkan terdapat 16 artikel Jurnal Nasional dan 2 artikel Jurnal Internasional. Data yang terkumpul kemudian akan dikompilasi, dianalisis, dan pada akhirnya akan disimpulkan sehingga mendapatkan sebuah kesimpulan.

\section{HASIL PENELITIAN}

Penelitian ini bertujuan tujuan mengetahui apa saja faktor-faktor yang seharusnya dimiliki oleh seorang guru sehingga dalam suatu proses pembelajaran guru mampu untuk menciptakan suatu pembelajaran yang baik, strategi dan gaya mengajar yang tepat, serta pengetahuan dan pengalaman yang maksimal. Dengan mengetahui dan memahami dari keempat hakekat pendidikan diatas, seorang pendidik diharapkan mendapat petunjuk dan tuntunan dalam melaksanakan proses pembelajaran, sehingga tujuan yang diharapkan dapat tercapai dengan baik dan maksimal. Idealnya dalam proses pembelajaran perlu ada komunikasi antara guru dan siswa yang mengandung unsur-unsur pedagogi.

Dalam proses pembelajaran, seorang guru harus mampu menciptakan suatu proses pembelajaran yang baik, strategi dan gaya dalam mengajar yang tepat, penguasaan ilmu dan seni dalam proses pembelajaran yang maksimal, serta penguasaan pengetahuan dan pengalaman yang masih baik, sehingga siswa dapat mengikuti proses pembelajaran dengan baik dan hasil yang didapatkan maksimal. Seorang guru pendidikan jasmani dalam proses pembelajaran harus memiliki beberapa konsep pengetahuan seperti:

\section{Pengetahuan Tentang Teori}

Pengetahuan tentang teori merupakan pengetahuan yang paling dasar yang harus dimiliki oleh seorang guru. Dalam pengetahuan teori, seorang guru akan terlihat seberapa luas pengetahuan dan wawasan yang dimilikinya. Dimana tanpa adanya pengetahuan teori seorang guru tidak akan mampu melaksanakan tugasnya dalam mendidik dan memberikan pengetahuan terhadap peserta didiknya. 


\section{Pengetahuan Penerapan Metode}

Pengetahuan penerapan merupakan pengetahua dimana seorang guru harus mengetahu metode-metode yang tepat dalam proses pembelajaran. Selain metode, guru juga harus menggunakan media pembelajaran yang tepat, agar siswa lebih mudah dan paham dalam menerima penyampaian materi dari guru.

\section{Pengetahuan Situasional}

Pengetahuan situasional merupakan pengetahuan dalam kemampuan guru mnengelola kelas dalam keadaan situasional. Proses pembelajaran di kelas tidak akan sepenuhnya sesuai dengan apa yang direncanakan sebelumnya. Banyak faktor-faktor yang mempengaruhi proses pembelajaran di sekolah sehingga tidak sesuai dengan apa yang kita rencanakan sebelumnya. Jadi, seorang guru harus mampu dalam menyikapi hal-hal yang bersifat situasional tersebut. Selain itu, ada beberapa faktor yang harus diketahui oleh seorang guru, agar proses pembelajaran dalam mencapai hasil yang maksimal, antara lain: (1) Mengenal Karakteristik Peserta Didik: Seorang guru harus mengetahui bagaiamana karakteristik dari siswa yang kita ajar, dari pengetahuan terhadap karakteristik siswa tersebut, guru dapat menggunakan metode-metode pembelajaran yang tepat dan sesuai dengan karakteristik siswa tersebut. (2) Mampu Mengembangkan Materi dan Metode Pembelajaran: Seorang guru harus mampu mengembangkan materi dan metode pembelajaran sesuai dengan keadaan lingkungan di sekolah tersebut. Karena keadaan masing-masing sekolah di seluruh daerah di Indonesia sangat berbeda. Banyak sekolah yang masih kekurangan sarana prasarana dalam kegiatan pembelajaran. (3) Menciptakan Suasana yang Menyenangkan: Dalam proses pembelajaran di kelas maupun di luar kelas, seorang guru harus mampu dalam menciptakan suasana kelas yang menarik, sehingga siswa dalam proses pembelajaran merasa senang, nyaman dan mudah dalam menerima materi yang diberikan oleh guru. (4) Mengembangkan Potensi Siswa: Dalam proses pembelajaran, guru harus mampu dalam melihat potensi-potensi yang dimiliki setiap individu siswa. Karena, tingkat pemahaman serta tingkat kemampuan masing-masing individu sangat berbeda. Jadi, seorang guru harus mampu mengembangkan potensi siswa yang dimilikinya.

Selain itu, seorang guru harus memiliki beberapa keterampilan dalam mengajar seperti keterampilan membuka dan menutup pembelajaran, keterampilan menjelaskan, keterampilan bertanya, keterampilan memberi penguatan, keterampilan menggunakan media pembelajaran, keterampilan membimbing diskusi kelompok kecil, keterampilan mengelola kelas, keterampilan mengadakan variasi dan keterampilan mengajar perorangan dan kelompok kecil (Suwarna, 2015).

\section{a. Keterampilan Membuka dan Menutup Pembelajaran}

Keterampilan dasar mengajar membuka pelajaran adalah kegiatan yang dilakukan oleh guru di awal pembelajara agar minat dan perhatiannya siswa terpusat pada apa yang akan dipelajarinya. Keterampilan dasar mengajar membuka pelajaran memiliki tujuan antara lain: (1) membantu siswa mempersiapkan dari awal agar dapat membayangkan materi yang akan dipelajari, (2) menimbulkan minat dan perhatian siswa terhadap materi pembelajaran.

Sedangkan kegiatan menutup pelajaran adalah kegiatan yang dilakukan oleh guru untuk mengakhiri sebuah pembelajaran. Keterampilan dasar mengajar seorang guru dalam menutup proses pembelajaran memiliki tujuan untuk: (1) mengetahui tingkat keberhasilan siswa seberapa jauh pemahamannya terhadap materi yang diberikan, (2) mengetahui tingkat keberhasilan guru terhadap keberhasilan dari proses pembelajaran. 


\section{b. Keterampilan Menjelaskan}

Keterampilan dasar menjelaskan dalam pembelajaran adalah keterampilan menyajikan materi secara lisan yang dilakukan secara sistematis untuk menunjukan adanya hubungan antara bagian satu dengan bagian lainnya, misalnya antara sebab dan akibat dan definisi dengan contoh. Tujuan memberikan penjelasan yaitu: (1) membimbing murid agar memahami materi yang diajarkan, (2) melibatkan murid untuk dapat memecahkan suatu masalah.

\section{c. Keterampilan Bertanya}

Bertanya adalah suatu keterampilan yang merangsang siswa agar lebih berfikir secara luas terkait materi yang diajarkan. Pertanyaan yang ditujukan kepada siswa bertujuan untuk: (1) mendorong siswa agar lebih berminat terhadap materi yang diajarkan, (2) memusatkan perhatian siswa terhadap materi yang dipelajari.

\section{d. Keterampilan Memberi Penguatan}

Keterampilan penguatan adalah keterampilan yang memberikan timbal balik terhadap proses pembelajaran, agar siswa lebih paham dan mendapat pengetahuan yang kuat terhadap materi yang dipelajari. Memberi penguatan bertujuan untuk: (1) meningkatkan perhatian siswa pada pelajaran, (2) meningkatkan motivasi belajar siswa.

\section{e. Keterampilan Menggunakan Media Pembelajaran}

Media pembelajaran merupakan alat bantu dalam menyampaikan informasi kepada siswa. Keterampilan dasar mengajar berupa keterampilan menggunakan media pembelajaran bertujua sebagai berikut: (1) memperjelas penyajian pesan oleh guru agar mudah dimengerti, (2) memperlancar jalannya proses pembelajaran.

\section{f. Keterampilan Membimbing Diskusi Kelompok Kecil}

Diskusi kelompok kecil adalah suatu proses pembelajaran yang teratur dalam lingkup kecil, dimana para siswa akan saling bertatap muka dalam proses memecahkan suatu masalah dalam sebuah diskusi. Keterampilan membimbing diskusi kelompok kecil bertujuan untuk: (1) siswa dapat saling memberi informasi atau pengalaman terhadap materi yang dipelajari, (2) siswa dapat mengembangkan pengetahuan dan kemampuan untuk berfikir dan berkomunikasi.

\section{g. Keterampilan Mengelola Kelas}

Pengelolaan kelas adalah keterampilan guru dalam mengatur jalannya proses pembembelajaran dikelas. Keterampilan ini bertujuan untuk: (1) mendorong siswa mengembangkan tingkah lakunya sesuai dengan tujuan pembelajaran, (2) membantu siswa mengehentikan tingkah lakunya yang menyimpang dari tujuan pembelajaran.

\section{h. Keterampilan Mengadakan Variasi}

Variasi dalam kegiatah belajar mengajar adalah proses seorang guru dalam memodifikasi sesuatu yang bertujuan untuk meningkatkan motivasi para siswa serta kejenuhan dan kebosanan terhadap hal-hal yang sudah terbiasa atau sering dilakukan dalam proses pembelajaran. Tujuan keterampilan ini adalah: (1) menimbulkan dan meningkatkan perhatian siswa kepada aspek-aspek pembelajaran, (2) memupuk tingkah laku yang positif terhadap guru dan sekolah dengan berbagai cara mengajar yang lebih hidup. 
i. Keterampilan Mengajar Perorangan dan Kelompok Kecil

Pada dasarnya mengajar perorangan memiliki ciri-ciri seperti: (1) terjadinya hubungan interpersonal antara guru dengan siswa, dan juga siswa dengan siswa, (2) siswa belajar sesuai dengan kecepatan dan kemampuan masing-masing.

Berdasarkan hal tersebut, dapat simpulkan bahwa tidak setiap siswa yang belajar sendiri dikatakan dalam pengajaran perorangan. Pengajaran dalam kelompok kecil memiliki ciri-ciri seperti pengajaran perorangan, akan tetapi memiliki perbedaan dengan pengajaran perorangan. Keterampilan dalam mengajar perorangan memiliki tujuan: (1) memberikan rasa tanggung jawab yang lebih besar kepada siswa, (2) memberi kesempatan kepada siswa untuk belajar lebih aktif. Sedangkan keterampilan mengajar kelompok kecil bertujuan: (1) meningkatkan kualitas pembelajaran melalui dinamika kelompok, (2) memberi kesempatan memecahkan masalah untuk berlatih memecahkan masalah dan cara hidup secara rasional dan demokratis.

\section{PEMBAHASAN}

Tujuan dilakukan penelitian ini adalah untuk mengetahui apa saja faktor-faktor yang seharusnya dimiliki oleh seorang guru sehingga dalam suatu proses pembelajaran guru mampu untuk menciptakan suatu pembelajaran yang baik, strategi dan gaya mengajar yang tepat, serta pengetahuan dan pengalaman yang maksimal. Menurut Asril (2010) proses pembelajaran lebih banyak ditentukan oleh tiga komponen yaitu tujuan mengajar, metode dan teknik mengajar, serta alat-alat pelajaran: (1) Tujuan Mengajar: Langkah awal yang harus dilakukan oleh seorang guru adalah menetapkan sebuah tujuan pembelajaran yang akan dicapai dari mata pelajaran tersebut dengan tujuan agar memudahkan mengarahkan kegiata belajar siswa dan memilih metode yang tepat. (2) Metode dan Teknik Mengajar: Dalam proses interaksi antara pendidik dan peserta didik, kedudukan metode mengajar sangatlah penting, karena pengertian metode tidaklah hanya sekedar suatu cara, tetapi merupakan teknik bagaimana cara kita menyampaikan materi agar lebih mudah dipahami oleh siswa. (3) Alat-Alat Pelajaran: Alat-alat peraga di sini digunakan sebagai sarana dalam menyampaikan informasi agar lebih mudah dimengerti oleh siswa. Selain itu, beberapa hal yang harus dikuasi oleh guru yaitu sebagai berikut:

\section{Pedagogi Olahraga}

Kompetesi pedagogik guru merupakan kemampuan seorang guru dalam mendidik dan mengurus peserta didik dalam proses pembelajaran (Nellitawati \& Boon, 2015). Kompetensi pedagogik merupakan sebuah pengetahuan, sikap, dan ketrampilan seorang guru dalam membelajarkan siswa di kelas (Mutohir, 2015). Guru dapat dikatakan baik dan bertanggung jawab dalam proses pembelajaran apabila guru tersebut membekali dirinya dengan berbagai macam-macam kompetensi pendukung kinerjanya dalam pembelajaran, termasuk kompetensi pedagogik (Hamdani, 2017). Pedagogi olahraga adalah suatu ilmu yang merupakan bagian dari ilmu keolahragaan, sebagai bagian dari ilmu keolahragaan, pedagogi olahraga merupakan gabungan antara ilmu pendidikan dan ilmu keolahragaan. Sedangkan, sumber lain mengatakan bahwa pedagogik adalah suatu teori yang dilakukan secara teliti, kritis, dan objektif dalam mengembangkan konsep-konsepnya yang berkaitan dengan hakekat manusia, anak, tujuan pendidikan, dan hakekat proses pendidikan (Hendriani, Nuryani, \& Ibrahim, 2018). 
Artinya, pedagogi olahraga adalah sebuah bidang ilmu yang mempelajari pendidikan melalui olahraga atau aktifitas fisik. Pedagogi olahraga merupakan bagian dari ilmu keolahragaan yang masih sangat muda di Indonesia, dimana melalui pedagogi olahraga diharapkan dapat berpotensi untuk mengintegrasikan subdisiplin dalam ilmu keolahragaan.

\section{Strategi Meningkatkan Kualitas Pembelajaran}

Strategi dalam meningkatkan kualitas pembelajaran sangat penting untuk diterapkan, berbagai metode sudah dilakukan yang bertujuan untuk meningkatkan kualitas pembelajaran dan mendapatkan hasil yang diinginkan. Terdapat beberapa jenis-jenis teknik pengawasan dalam proses pembelajaran pendidikan jasmani untuk meningkatkan aktivitas belajar siswa yaitu seperti berdiri di pinggir lapangan, mendekati siswa, mengingat nama, pengawasan melekat, mengabaian kasus tertentu, secara terpadu, dan modeling (Sarwono, 2014).

Penjelasan mengenai beberapa jenis-jenis teknik pengawasan dalam proses pembelajaran pendidikan jasmani adalah sebagai berikut: (1) Berdiri di Pinggir Lapangan: Seorang guru akan lebih baik apabila berdiri di pinggir lapangan ketika proses pembelajaran pendidikan jasmani berlangsung di lapangan. Dengan cara ini, siswa akan merasa diawasi oleh guru dan akan lebih serius dalam mengikuti proses pembelajaran. Sebaliknya, apabila guru hanya duduk dan tidak mengawasi siswa dalam proses pembelajaran, siswa kemungkinan besar akan tidak serius dan bercanda dalam mengikuti proses pembelajaran. (2) Mendekati Siswa: Dengan cara mendekati siswa atau kelompok dalam proses pembelajaran, secara tidak langsung akan mengurangi pasifnya siswa dalam kegiatan pembelajaran. Sekalipun guru tidak bicara, tetapi dengan cara mendekati siswa, siswa tersebut akan merasa terdorong untuk mengikuti perintah dari guru yang diberikan sebelumnya, dengan demikian siswa yang pasif dalam proses pembelajaran akan menjadi lebih aktif sehingga akan berpengaruh terhadap hasil dari pembelajaran tersebut. Namun, bukan berarti seorang guru hanya diam dan mendekati siswa tersebut, tetapi setelah siswa aktif kembali dalam proses pembelajaran, guru sebaiknya mendekati siswa atau kelompok lain yang masih pasif dalam proses pembelajaran pendidikan jasmani ataupun membantu dan mengontrol jalannya pembelajaran pendidikan jasmani. (3) Mengingat Nama: Salah satu hal yang penting dalam proses pembelajaran adalah mendapat perhatian dari siswa, ketika seorang guru mengetahui nama siswa, guru dengan cara memanggil nama siswa tersebut dari jauh secara tidak langsung akan mempengaruhi siswa tersebut agar lebih fokus dalam proses pembelajara. Tetapi, pada siswa yang namanya masih belum diketahui oleh guru, guru mungkin harus mendekati siswa tersebut untuk menegur agar lebih fokus dalam proses pembelajaran. Jadi, pentingnya seorang guru untuk menghafal nama siswa tersebut agar lebih mudah mengontrol proses jalannya pembelajaran. (4) Pengawasan Melekat: Pengawasan melekat memberikan kesan kepada siswa bahwa gurunya sedang mengamati dan mengawasi siswa dalam proses pembelajaran. Sehingga siswa akan menjadi serius dan mengurangi aktifitas-aktifitas lain dari proses pembelajaran tersebut. (5) Mengabaikan Kasus Tertentu: Dalam strategi ini, seorang guru boleh mengabaikan kasus tertentu semasih kasus tersebut tidak mengganggu proses jalannya kegiatan pembelajaran. (6) Secara Terpadu: Secara terpadu yaitu kemampuan guru pendidikan jasmani dalam mengatasi beberapa masalah atau kejadian dalam proses pembelajaran, misalnya empat nama siswa. Dengan demikian, dengan strategi secara terpadu lama kelamaan guru akan mengingat seluruh nama siswanya dengan baik walaupun menghafalnya sedikit demi sedikit. (7) Modeling: Modeling di sini dimaksud 
adalah suatu strategi dimana seorang guru menunjuk atau memilih siswa yang melakukan pelaksanaan teknik dalam olahraga dengan baik. Sehingga siswa tersebut merasa diperhatikan dan otomatis mempengaruhi siswa lain agar mampu melakukan hal yang sama. Sebagai contoh guru menunjuk salah satu siswa untuk mempraktekan teknik dasar passing di hadapan siswa lainnya. Cara seperti ini akan lebih efektif karena siswa ingin diperhatikan oleh gurunya.

\section{Model-Model Pembelajaran}

Belajar merupakan suatu proses usaha untuk memperoleh perubahan tingkah laku tertentu yang dilakukan secara sadar dan diamati secara langsung maupun tidak langsung. Dalam suatu proses pembelajaran, guru harus mampu mengelola kelas agar dapat berjalan dengan maksimal dan terkendali, selain itu siswa diharapkan dapat mengikuti proses pembelajaran yang diberikan oleh guru. Banyak metode-metode yang bisa dilakukan oleh seorang guru, salah satunya adalah dengan cara memberikan model-model pembelajaran yang dapat merangsang siswa agar lebih fokus dan aktif dalam suatu proses pembelajaran, beberapa model-model permbelajaran tersebut antara lain adalah model pembelajaran kooperatif, model pembelajaran berbasis masalah dan model pembelajaran penemuan (Suprihatiningrum, 2016):

a. Model Pembelajaran Kooperatif

Model pembelajaran kooperatif atau cooperative learning yaitu model pembelajaran yang mana siswa dituntut untuk bekerja sama dalam kelompok kecil yang sudah dibentuk dan saling membantu dalam proses pembelajaran dalan memecahkan suatu masalah yang dihadapinya. Model ini sudah sangat banyak diterapkan dalam pembelajaran pendidikan jasmani (Gazali, 2016: Candra, 2017: Novion, 2018: Indrawan, Priana, \& Rubiana, 2018: Panuntun, 2020).

b. Model Pembelajaran Berbasis Masalah

Model pembelajaran berbasis masalah atau sering disebut problem bassed learning adalah suatu model pembelajaran dimana siswa diberikan suatu permasalahan tertentu oleh guru, dimana diharapkan dapat menyusun pengetahuan mereka sendiri, mengembangkan inkuiri, serta keterampilan dalam berfikir lebih tinggi. Model ini sudah sangat banyak diterapkan dalam pembelajaran pendidikan jasmani (Hamzah \& Hadiana, 2018: Ladjar, Juliantine, Mulyana, Berliana, 2018: Rohmansyah, 2018: Panuntun, 2020).

c. Model Pembelajaran Penemuan

Model pembelajaran penemuan atau discovery learning merupakan model pembelajaran yang bertujua agar siswa didorong untuk dapat belajar aktif melalui keterlibatan aktif mereka sendiri dengan konsep-konsep, dan prinsip-prinsip. Model ini sudah sangat banyak diterapkan dalam pembelajaran pendidikan jasmani (Ladjar, Juliantine, Mulyana, Berliana, 2018: Sukarini, 2020)

Menurut Suprihatiningrum (2016) terdapat beberapa macam strategi dalam proses pembelajaran yang sangat perlu dilakukan oleh seorang guru yaitu strategi mengulang, strategi elaborasi, strategi organisasi dan strategi metakognitif:

a. Strategi Mengulang

Strategi mengulang ini terdapat dua macam, yaitu strategi mengulang sederhana dan strategi mengulang komplek, dimana dalam strategi ini dilakukan dengan cara menggaris bawahi ide-ide utama dan membuat catatan pinggir dalam proses pembelajaran, yang bertujuan untuk meningkatkan kemampuan siswa dalam proses pembelajaran di kelas. 


\section{b. Strategi Elaborasi}

Strategi elaborasi ini dilakukan dengan cara menambahkan rincian materi saat proses pembelajaran sehingga informasi baru akan lebih bermakna bagi siswa. Salah satu caranya yaitu dengan cara membuat kode. Beberapa contoh strategi elaborasi adalah antara lain note taking (pembuatan catatan) berdasarkan ide-ide utama dari materi ajar yang digunakan.

c. Strategi Organisasi

Strategi organisasi ini merupakan strategi yang melatih keterampilan mengorganisasikan ide-ide baru dalam mempelajari suatu materi di kelas. Siswa perlu membuat kata-kata kunci dan membuatnya dalam bentuk baru, sehingga mudan untuk dimengerti.

d. Strategi Metakognitif

Strategi metakognitif adalah pengetahuan yang dimiliki seseorang tentang pembelajaran diri sendiri atau berpikir tentang kemampuan yang dimilikinya untuk menggunakan strategi-strategi dalam belajar tertentu dengan benar.

Seorang guru harus mampu menguasai 4 strategi di atas sebagai dasar dalam proses pembelajaran. Dimana, dengan menguasai 4 strategi tersebut, diharapkan nantinya dari hasil pelaksanaan proses pembelajaran dapat berjalan secara maksimal. Seorang pendidik dalam suatu proses pembelajaran harus memiliki beberapa pemahaman mengenai prinsip-prinsip pembelajaran, dimana bertujuan agar dari pembelajaran tersebut dapat berhasil secara maksimal, minimal harus ada 4 pemahaman yang dimiliki oleh seorang guru dalam konteks pendidikan yaitu hakekat manusia, hakekat anak, hakekat pendidikan, dan hakekat (Rahman, 2018).

\section{KESIMPULAN}

Guru harus mampu menguasai materi pembelajaran yang luas, cara penerapan di kelas dalam menggunakan metode-metode yang tepat, serta mampu mengelola kelas agar proses pembelajaran dapat berjalan dengan baik dan mencapai hasil yang maksimal. Kemampuan dalam menguasi suatu materi pembelajaran harus diimbangi dengan kemampuan dalam bagaimana cara seorang guru untuk menyampaikan materi pembelajaran tersebut agar peserta didik mampu menerima materi yang diajarkan. Diharapkan dengan adanya penelitian ini, kedepannya guru mampu untuk menerapkan metode-metode pembelajaran yang tepat saat proses pembelajaran dikelas sehingga pembelajaran dapat berjalan dengan baik dan mendapatkan hasil yang maksimal. Jika seorang guru hanya menguasai materi pembelajaran tetapi tidak mampu dalam menyampaikan materi serta mengelola jalannya proses pembelajaran maka tujuan dari pembelajaran tersebut tidak akan tercapai. Jadi antara penguasaan materi pembelajaran dan penerapan metode-metode dalam pembelajaran harus seimbang dalam proses pembelajaran tersebut. Semua metode, media, referensi, dan sebagainya tidak akan berarti apabila seorang guru tidak mampu dalam memerankan tugasnya dengan baik.

Dalam penelitian ini masih terdapat keterbatasan yaitu sulitnya mencari referensi di masa pandemi Covid-19. Dengan adanya penelitian ini, diharapkan dapat membantu guru dalam memahami tugas pokoknya dalam proses pembelajaran serta menyadari bahwa penting bagi setiap guru untuk mendalami ilmu pedagogi. Bagi peneliti lainnya, diharapkan mampu untuk membuat sebuah penelitian mengenai ilmu pedagogi olahraga yang lebih luas. 


\section{DAFTAR PUSTAKA}

Alfrey, L., Enright, E., \& Rynne, S. (2017). Letters from Early Career Academics: the Physical Education and Sport Pedagogy Field of Play. Sport, Education and Society, 22(1), 5-21. https://doi.org/10.1080/13573322.2016.1242479

Apriani, L., Alpen, J., \& Arismon, A. (2020). Tingkat percaya diri dan keterampilan micro teaching. Edu Sportivo: Indonesian Journal of Physical Education, 1(1), 42-49. https://doi.org/10.25299/es:ijope.2020.vol1(1).5155

Asril, Z. (2010). Micro Teaching. Jakarta: Rajawali Pers.

Budiman, H. (2017). Peran Teknologi Informasi dan Komunikasi Dalam Pendidikan. Al-Tadzkiyyah: Jurnal Pendidikan Islam, 8(1), 31-43. https://doi.org/10.24042/atjpi.v8i1.2095

Candra, O. (2017). Pengaruh Metode Kooperatif Terhadap Keterampilan Bermain Bolabasket Pada Siswa Puteri Kelas VIII di SMP Negeri 9 Pekanbaru. Journal Sport Area, 2(1), 45-52. https://doi.org/10.25299/sportarea.2017.vol2(1).452

Danardono, H. (2015). Isi Pedagogi Olahraga. Jurnal Ilmiah Penjas, 1(2), 37-50.

Gazali, N. (2016). Pengaruh Metode Kooperatif dan Komando Terhadap Keterampilan Teknik Dasar Bermain Sepakbola.Journal Sport Area,1(1), 56-62. https://doi.org/10.25299/sportarea.2016.vol1(1).373

Haag. (1989). Research in "Sport Pedagogy" - One Field of Theoretical Study in The Science of Sport. Journal Revue Internationale de l'Education, 35, 5-16. http://www.jstor.org/stable/3444617

Hamdani. (2017). Hubungan Kompetensi Pedagogik dan Motivasi Mengajar dengan Hasil Belajar Siswa Kelas XI Pada Mata Pelajaran Fikih di MAN 2 Model Medan. Jurnal ANSIRUN, 16(2), 113-114.

Hamzah, B., \& Hadiana, O. (2018). Pengaruh Penggunaan Model Problem Based Learning Terhadap Keterampilan Passing Dalam Permainan Futsal. JUARA: Jurnal Olahraga, 3(1), 1-7. https://doi.org/10.33222/juara.v3i1.210

Hendriani., Nuryani., \& Ibrahim. (2018). Pedagogik Literasi Kritis; Sejarah, Filsafat dan Perkembangannya di Dunia Pendidikan. Jurnal Ilmu Pendidikan, 55(5), 503510.

Hiryanto. (2017). Pedagogi, Andragogi dan Heutagogi Serta Implikasinya Dalam Pemberdayaan Masyarakat. Jurnal Dinamika Pendidikan, 6(2), 541-549.

Husdarta. (2010). Sejarah dan Filsafat Olahraga. Bandung: Alfabeta. 
Indrawan, B., Priana, A., \& Rubiana, I. (2018). Upaya Meningkatkan Hasil Belajar Materi Jenis Kelainan Anak Berkebutuhan Khusus (ABK) Pada Mata Kuliah Penjas Adaptif Dengan Menggunakan Model Pembelajaran Kooperatif Tipe Group Investigasi (GI). Journal Sport Area, 3(1), 1-5. https://doi.org/10.25299/sportarea.2018.vol3(1).1575

Kirom. (2011). Filsafat Ilmu dan Arah Pengembangan Pancasila: Relevansinya Dalam Mengatasi Persoalan Kebangsaan. Jurnal UGM. 21(2), 99-17.

Ladjar, M. A. B., Juliantine, T., Mulyana., \& Berliana. (2018). Pengaruh Model ProblemBased Learning dan Discovery Learning serta Kecerdasan Intelektual terhadap Berpikir Kreatif. Jurnal Pendidikan Jasmani dan Olahraga, 3(1), 22-33. https://doi.org/10.17509/jpjo.v3i1.9837

Mutohir, M. (2015). Revitalisasi Interaksi Pedagogik Guru Dengan Siswa Dalam Pembelajaran. Jurnal Pendidikan Agama Islam, 1(1), 1-9. https://doi.org/10.15294/miki.v1i1.1128

Nellitawati, \& Boon. (2015). Hubungan Peranan Kepemimpinan Kepala Sekolah Dengan Kompetensi Pedagogik Guru di SMK Negeri 2 Kota Padang. Jurnal Ilmiah Ilmu Pendidikan, 15(2), 1-2.

Novion, Z. (2018). Implementasi Model Pembelajaran Kooperatif Tipe Teams Games Tournament (TGT) Untuk Meningkatkan Hasil Belajar Siswa Pada Materi Menganalisis Teknik Dasar Passing Dalam Permainan Sepak Bola. Journal Sport Area, 3(1), 87-93. https://doi.org/10.25299/sportarea.2018.vol3(1).1412

Panuntun, F. (2020). Pengaruh Model Pembelajaran Kooperatif Teams Games Tournament (TGT) dan Problem Based Learning (PBL) Terhadap Hasil Belajar Sepak Bola (Dribbling) Pada Siswa Kelas XI SMK HKTI 2 Banjarnegara. Journal of Sport Coaching and Physical Education, 5(1), 19-23. https://doi.org/10.15294/jscpe.v5i1.36807

Rahman. (2018). Urgensi Pedagogik Dalam Pembelajaran dan Implikasinya Dalam Pendidikan. Jurnal Pendidikan Islam, 2(1), 187-192. https://doi.org/10.29240/bjpi.v3i1.358

Rifma. (2013). Problematika Kompetensi Pedagogik Guru Sekolah Dasar. Jurnal Media Ilmu Keolahragaan Indonesia, 57-65. https://doi.org/10.15294/miki.v5i2.7890

Rohmansyah, N. A. (2018). Pengaruh Model Pembelajaran Problem Based Learning Terhadap Kemampuan Pemahaman Konsep Pendidikan Jasmani pada Pembelajaran Tematik Terintegrasi Siswa Kelas IV. Jurnal Penjakora, 4(2), 28-35. http://dx.doi.org/10.23887/penjakora.v4i2.13364

Rusmawati, I. (2016). Penerapan Permainan Tradisional Terhadap Gerak Dasar Motorik Siswa Dalam Pembelajaran Pendidikan Jasmani, Olahraga dan Kesehatan Pada Siswa Kelas V SDN Margomulyo 1 Bojonegoro. Jurnal Pendidikan Olahraga dan Kesehatan, 4(2), 435-440. 
Sarwono. (2014). Meningkatkan Aktivitas Belajar dan Disiplin Siswa Dalam Pembelajaran Pendidikan Jasmani. Phederal: Physical Education, Health and Recreation Journal, 8(1), 1-7.

Suprihatiningrum. (2016). Strategi Pembelajaran. Yogyakarta: Ar-Ruzz Media.

Sukarini, N. N. (2020). Meningkatkan Hasil Belajar Siswa Pada Pendidikan Jasmani Olahraga Kesehatan (PJOK) Materi Teknik Dasar Memegang Raket dalam Permainan Bulu Tangkis Melalui Penerapan Model Pembelajaran Discovery Learning. Journal of Education Action Research,4(3), 371-377. http://dx.doi.org/10.23887/jear.v4i3.26751

Suwarna. (2015). Pengajaran Mikro Dalam Pembelajaran. Yogyakarta: Tiara Wacana. 